\title{
Omeprazole as an Adjuvant to Praziquantel in Treatment of Experimental Schistosomiasis Mansoni
}

\author{
ASMAA R. EL LAKANY, M.Sc.*; DINA I. EL GENDY, M.D.*; HANAN A. ALSHENAWY, M.D.** and \\ AMIRA E. ABDEL GHAFFAR, M.D.*
}

The Departments of Medical Parasitology* and Pathology**, Faculty of Medicine, Tanta University, Egypt

\begin{abstract}
Background: Schistosomiasis is an important parasitic disease. It has a chronic course with noticeable residual effects on health. Praziquantel (PZQ) is recommended by the WHO as the first line in treatment of schistosomiasis. Unfortunately, it has low efficacy against schistosomula and the juveniles stages which can compromise its efficacy. This further needs more research to find new drugs that improve the effectiveness of PZQ. Omeprazole has been found experimentally to have antiparasitic properties against many parasites such as Leishmania donovani, Plasmodium falciparum, Trichomonas vaginalis, Entamoeba histolytica and Giardia lamblia.
\end{abstract}

Aim of the Study: The aim of this study was to evaluate the efficacy of omeprazole as an adjuvant with PZQ in mice infected with Schistosoma mansoni (S. mansoni).

Material and Methods: For this aim, 100 laboratory bred clean male Swiss albino mice were divided into three groups including group I (Normal), group II (Control), group III infected and treated at 4 weeks post infection (P.I.). Group III was divided into 3 subgroups a (treated with PZQ), b (treated with omeprazole) and c (combined treatment). At 6 weeks P.I., all mice were submitted to the following: Count of juveniles worms, liver egg load, histopathological examination of the liver.

Results: The results showed significant reduction of counts of juveniles worms, liver egg loads and improvement of the pathological changes in the liver in combined treatment group at 6 weeks P.I. as compared to PZQ treated group.

Conclusions: From these results, it was concluded that combination of omeprazole with PZQ shows synergistic effect in the treatment of S. mansoni-infected mice. Therefore, further studies should be done to establish the mechanisms of action of omeprazole and to examine its beneficial effects.

Key Words: Schistosoma mansoni-Omeprazole-Praziquantel efficacy-Granuloma.

\section{Introduction}

SCHISTOSOMIASIS is a worldwide disease that kills over 200,000 people annually [1] . It is typically affecting the poor and the underprivileged in 74

Correspondence to: Dr. Asmaa R. El Lakany, E-Mail: arashad20@yahoo.com developing countries with up to 600 million people infected and 800 million, mostly children, at risk of contracting the disease $[2,3]$. Furthermore, the disease has now spread to regions that were nonendemic before and it is feared that building of dams, development of irrigation systems and global warming could further increase schistosomiasis transmission [4].

PZQ is now the drug of choice in the treatment of schistosomiasis. This is mainly because it is given as a single oral dose, has no severe side effects and its cost is low. However, it shows low efficacy against schistosomula and its juveniles stages, allowing lower cure rates in areas with high endemicity $[\mathbf{5 , 6 ]}$. Thus, there is a pressing need to investigate alternative or synergistic drugs against S. mansoni.

Omeprazole is a proton pump inhibitor which acts on gastric $\mathrm{H}+, \mathrm{K}+$ ATPase [7] . It has a specific activity against Helicobacter pylori in vitro [8] and is used in combination with antibiotics to treat infections with this bacteria [9]. It is also effective in killing promastigotes as well as intracellular amastigotes of Leishmania donovani, [10] with the likely target being the $\mathrm{H}+, \mathrm{K}+\mathrm{ATPase}$ on the plasma membrane of the parasite. Furthermore, it was found to have an in vitro activity against other parasites [11] . In addition, Almeida and his colleagues [12] concluded that omeprazole has a synergistic effect against $\mathrm{S}$. mansoni when tested in vitro in combination with PZQ. Therefore, we found that it would be useful to investigate the effect of the combination of PZQ and omeprazole against $\mathrm{S}$. mansoni worms in vivo.

\section{Patients and Methods}

\section{Experimental animals:}

This study was done in Medical Parasitology Department, Faculty of Medicine, Tanta University 
during the period from March 2017 to March 2018. It was carried out on 100 laboratory bred parasitefree male Swiss albino mice 6 weeks old and 20$25 \mathrm{gm}$ weight obtained from Theodore-Bilharz Research Institute (Giza, Egypt). In accordance with the institutional guidelines, all mice were allowed to adapt for 4 days before they were used in the experiment.

\section{Drug regimen:}

- Praziquantel: (Distocide; 600mg tablet, EIPICO. Pharmaceuticals, Egypt). It was administered orally to each mouse in a dose of $250 \mathrm{mg} / \mathrm{kg}$ body weight for two doses four hours apart using one $\mathrm{ml}$ syringe equipped with a blunt, 18-gauge needle according to Shaheen et al., [13] .

- Omeprazole: (Omepral; 20mg capsules, Memphis, Pharmaceuticals, Egypt). It was administered orally to each mouse in a dose of $20 \mathrm{~g} / \mathrm{d} y \mathrm{y}$ for seven consecutive days according to Tian et al., [14].

\section{Experimental design:}

All mice in the infected groups were infected subcutaneously with S. mansoni cercariae " $60 \pm 10$ cercariae/animal" suspended in $0.2 \mathrm{ml}$ solution as described by Holanda and colleagues [15]

\section{Mice were divided into three groups:}

Group I (Normal): (20 mice) uninfected control.

Group II (Control): (20 mice) S. mansoniinfected but untreated control.

Group III: (60 mice) S. mansoni-infected mice that received treatment starting four weeks P.I. This group was divided into three subgroups as following:

- Subgroup IIIa (PZQ) (20 mice): Were treated with PZQ only.

- Subgroup IIIb (Omeprazole) (20 mice): Were treated with omeprazole only.

- Subgroup IIIc (Combined) (20 mice): Were treated with PZQ and omeprazole.

Six weeks P.I., the animals were sacrificed and submitted to the following:

Parasitological study:

Juvenile worms count employed the well established animal perfusion technique which involved incision of the portal vein and perfusion of citrated saline through the descending aorta [16]
Liver egg load was performed using defined sections of the liver of each mouse. The number of S. mansoni ova was estimated using the potassium hydroxide digestion method according to Cheever [17]. The recorded number was expressed for the liver after correction to the liver weight [17].

\section{Histopathological study:}

It involved treatment of liver sections with $10 \%$ neutral formalin and preparation of $5 \mathrm{~m}$ hick sections. Selected sections were stained with heamatoxylin and eosin stain. These sections were examined microscopically to determine the number of the granulomas and their average diameter in addition to the description of granuloma tissue [18,19]

\section{Ethics statement:}

The study protocol was approved and conducted according to the guidelines of the Laboratory Animal Centre for Research Ethics Committee at Faculty of Medicine, Tanta University (code number 3 1446/03/17).

\section{Statistical analysis:}

These data were analyzed by one-way ANOVA followed by Tukey's multiple comparison as a post hoc test to determine significance of differences between groups using Statistical Package for Social Sciences (SPSS) (SPSS Inc., Chicago, Illinois, USA), software for windows, version [21]. The difference was considered statistically non significant when $(p>0.05)$, significant when $(p<0.05)$, and highly significant when $(p<0.001)$.

\section{Results}

\section{Effects on S. mansoni worms count:}

The effect of omeprazole as compared to PZQ on juvenile worms of S.mansoni was assessed in this study by measuring the mean number of worms recovered from mice by perfusion technique (Table 1). At 6 weeks P.I., there was a statistical significant difference among all studied groups $(p<0.001)$. The mean number of worms recovered from the control group was $21.95 \pm 4.29$. It was decreased statistically in both treated groups either with PZQ or combined with a high significant difference between both groups $(p<0.001)$. However, No statistical significant difference could be detected in omeprazole treated group $(p>0.05)$ as the mean number of worms recovered was 21. 10 \pm 5.27 . 
Table (1): Juvenile worms count (mean \pm SD) recovered from all studied groups at 6 weeks P.I. $(n=10)$.

\begin{tabular}{|c|c|c|c|c|c|}
\hline \multirow{2}{*}{\multicolumn{2}{|c|}{ Groups }} & \multicolumn{2}{|c|}{$\begin{array}{l}\text { Juvenile worms count } \\
\text { (6 weeks P.I.) }\end{array}$} & \multicolumn{2}{|c|}{ ANOVA } \\
\hline & & Mean \pm SD & $\begin{array}{l}\text { Reduction } \\
\text { percentage }\end{array}$ & $\mathrm{F}$ & $\begin{array}{c}p- \\
\text { value }\end{array}$ \\
\hline \multirow{4}{*}{\multicolumn{2}{|c|}{$\begin{array}{l}\text { Control group } \\
\text { PZQ group } \\
\text { Omeprazole group } \\
\text { Combined group }\end{array}$}} & $21.95 \pm 4.29$ & & \multirow{4}{*}{131.766} & \multirow[t]{4}{*}{$<0.001 *$} \\
\hline & & $6.85 \pm 3.30$ & 68.79 & & \\
\hline & & $21.10 \pm 5.27$ & 3.87 & & \\
\hline & & $2.32 \pm 1.16$ & 89.43 & & \\
\hline \multicolumn{6}{|c|}{ Post Hoc LSD } \\
\hline$p_{1}$ & $p_{2}$ & $p_{3}$ & $p_{4}$ & $p_{5}$ & $p_{6}$ \\
\hline$<0.001^{*}$ & 0.897 & $<0.001 *$ & $<0.001 *$ & $<0.004^{*}$ & $<0.001^{*}$ \\
\hline
\end{tabular}

$p 1=$ Comparison between control and PZQ groups.

* Significant $p$-value $<0.05$

$p 2=$ Comparison between control and omeprazole groups

$* *$ Highly significant $p$-value $<0.001$

$p 3=$ Comparison between control and combined groups.

$p 4=$ Comparison between PZQ and omeprazole groups.

$p 5=$ Comparison between PZQ and combined groups.

$p 6=$ Comparison between omeprazole and combined groups

$\mathrm{N}=$ Number of studied mice in each group.

- Reduction percentage: Percentage of reduction between each group and control group.

\section{Liver egg count:}

Fig. (1) showed that there was a highly statistical significant difference among all studied groups at different durations P.I. $(p<0.001)$. At 6 weeks P.I., the mean number of $\mathrm{S}$. mansoni ova/gram liver in the control group was $5472.20 \pm 1939.06$, while it was decreased in both PZQ and combined groups with a high statistical significant difference between both groups $(p<0.001)$. The mean number of ova in PZQ group was $990.40 \pm 152.95$, while in combined group was $176.10 \pm 43.56$. However, No statistical significant difference could be detected in omeprazole treated group $(p>0.05)$ as the mean number of S. mansoni ova/gram liver was $4749.40 \pm 1590.67$.

Histopathological findings of the liver parenchyma 6 weeks P.I.:

Number and diameter of hepatic granulomas/liver section:

The effect of omeprazole as compared to PZQ on the mean number of granulomas/liver section of liver sections stained with heamatoxyline \& eosin is shown in Table (2). At 6 weeks P.I., when comparing the mean number of hepatic granulomas/liver section in control group with that of other groups, it was found that there was significant decrease in both PZQ and combined groups, but the decrease was not significant in omeprazole group. Additionally, there was significant decrease in combined group in comparison with other groups.

In infected-untreated mice sacrificed 6 weeks P.I., liver sections showed multiple portal and parenchymal granulomas of cellular and fibrocellular types. Cellular granulomas showed collection of inflammatory cells with predominant lymphocytes, histocytes, epithelioid cell, plasma cell and eosinophils with scanty fibrous tissue (Fig. 2A\&B). As regards the effect of PZQ on bilharzial hepatic pathology, the number and size of granulomas detected was decreased significantly. The majority of granulomas were cellular formed of mononuclear cells mainly lymphocytes and plasma cell (Fig. 2C\&D). In omeprazole group, liver sections showed decrease in the size of granulomas which are mainly cellular (Fig. 3A\&B). In combined group, liver sections showed scanty small hepatic granulomas and marked improvement in hepatic pathology (Fig. 3C\&D).

Table (2): The number / liver section and diameter ( Im of hepatic granulomas in infected mice in the different studied groups at 6 weeks P.I. $(n=10)$

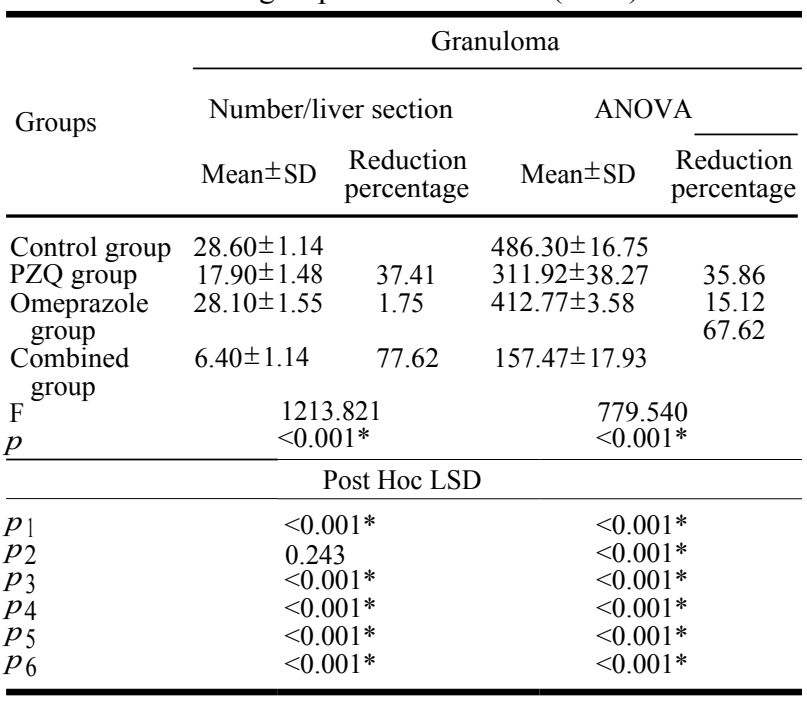

* Significant $p$-value $<0.05$

** Highly significant $p$-value $<0.001$

$p 1=$ Comparison between control and PZQ groups.

$p 2=$ Comparison between control and omeprazole groups.

$p 3=$ Comparison between control and combined groups.

$p 4=$ Comparison between PZQ and omeprazole groups.

$p 5=$ Comparison between PZQ and combined groups.

$p 6=$ Comparison between omeprazole and combined groups

$\mathrm{N}=$ Number of studied mice in each group.

- Reduction percentage: percentage of reduction between each group and control group.

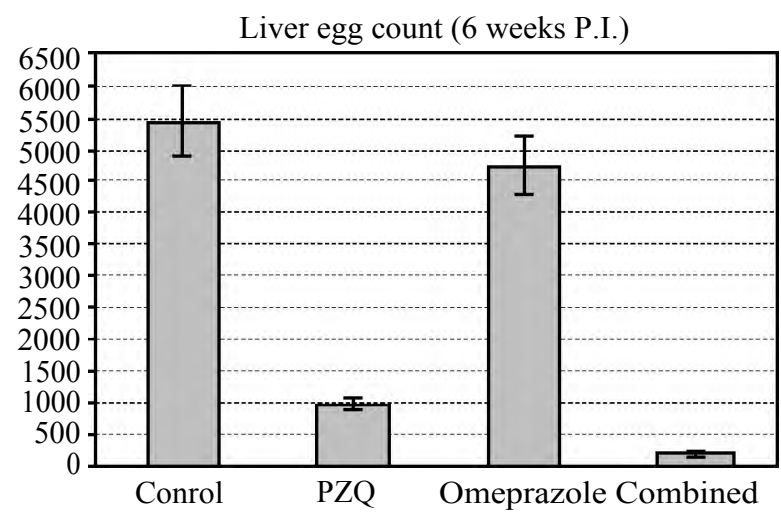

Fig. (1): Mean values of S. mansoni eggs/gm liver recovered from the studied groups at 6 weeks P.I. 

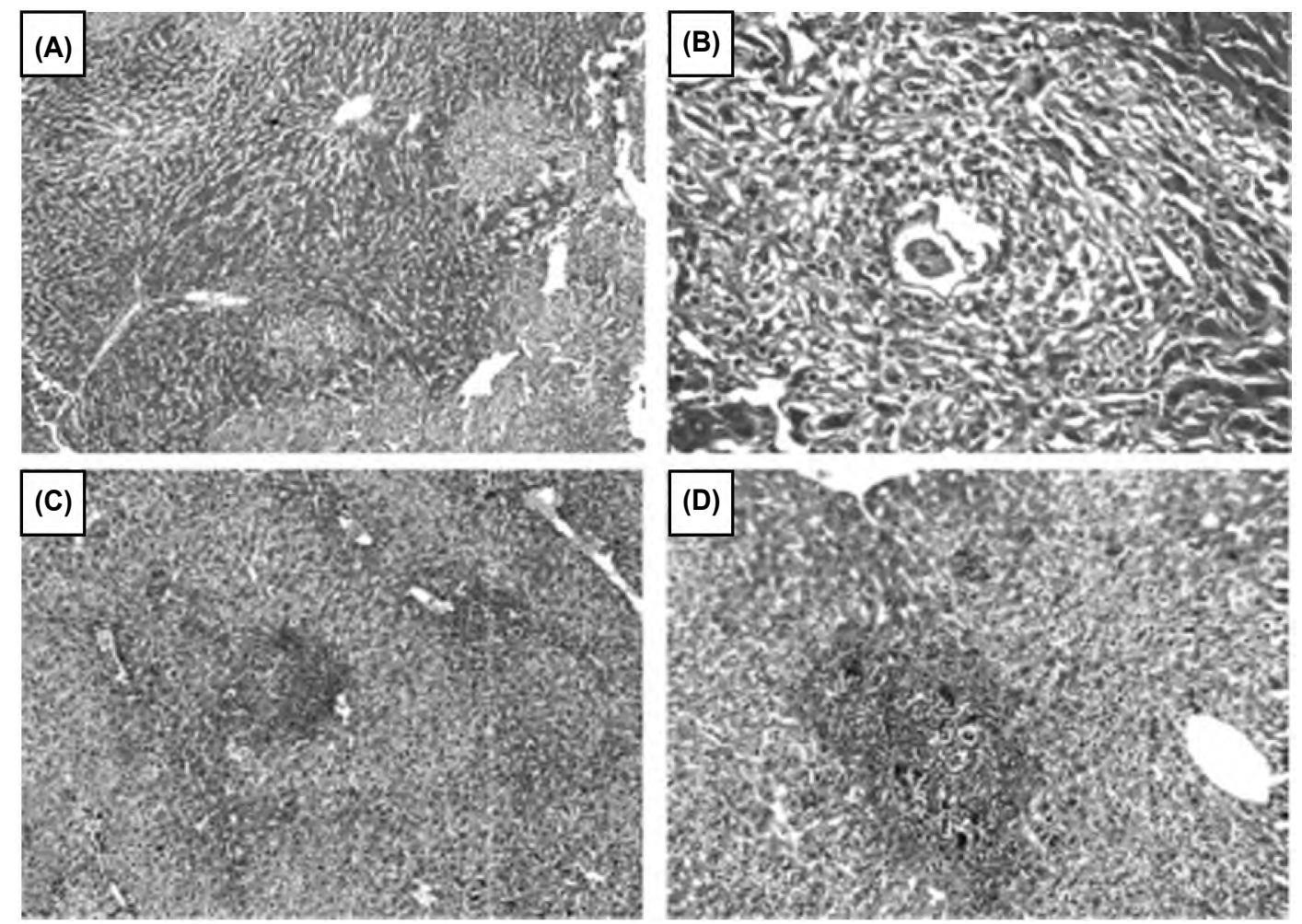

Fig. (2): Photomicrograph of a liver section 6 weeks P.I. (A) from the control group showing many granulomatous collections seen within the portal tracts distorting them (H\&Ex40); (B) from the control group showing schistosomal granuloma around the ova surrounded by a collection of lymphocytes, plasma cell and esinophils with scanty fibrous tissue (H\&Ex400); (C) from the PZQ group showing decrease in the number and size of granulomas (H\&Ex40); (D) Higher magnification of the previous image to illustrate the cellular nature of the granuloma as it is formed mainly of lymphocytes and plasma cells (H\&Ex200).
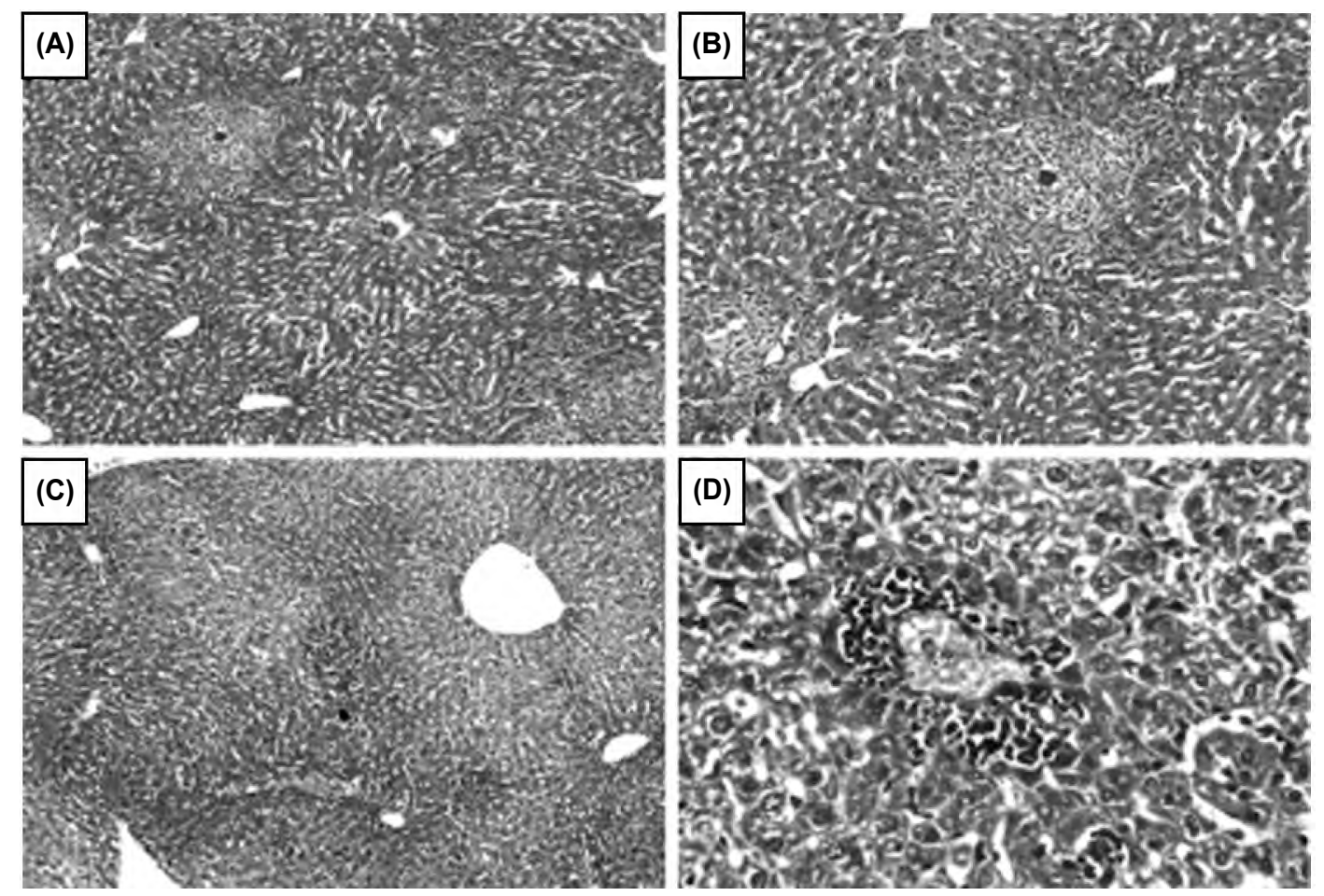

Fig. (3): Photomicrograph of a liver section 6 weeks P.I. (A) from the omeprazole group showing many granulomas of moderate size seen in the portal tracts (H\&Ex40); (B) Higher magnification of the previous image to illustrate the cellular nature of the granuloma as it is formed mainly of lymphocytes and plasma cells (H\&Ex200); (C) from the combined group showing very few and small granulomas scattered among the liver tissue (H\&Ex40); (D) Higher magnification of the previous image showing small cellular granulomas formed mainly of few lymphocytes and plasma cells (H\&Ex400). 


\section{Discussion}

Schistosomiasis is an important endemic disease which is extensively distributed with high rates in various countries in Africa, Asia and South America [20]. It is currently estimated to infect more than 200 million people worldwide and ranks second only to malaria in terms of the extent of endemic areas and the number of infected people [21]. World Health Organization (WHO) considers this disease as a major problem affecting the quality of life of patients with consequent economic effects on governments [22]. Occurance of hepatic periportal fibrosis is one of the most common morbid complications of schistosomiasis mansoni [23]. The management of this disease depends mostly on chemotherapy which is given with the aim of achieving complete cure or at least reducing the incidence of morbidity. Optimum dose can also lessen the extension of infection in endemic area [24].

The drug of choice for treatment of schistosomiasis is PZQ. This drug is thought to be safe with a broad spectrum of activity [25]. Since PZQ was developed, being highly effective and safe antischistosomal drug [26], it has replaced other schistosomicidal agents to become the only drug of choice for eradication of all major species of schistosomes and has played a very critical role in the control program against Schistosoma for more than three decades [27]

The availability of only one single antischistosomal drug is alarming as it carries the potential risk of the development of drug resistance. Recently PZQ-resistant isolates of S. mansoni have been established [28]. In addition, reduced cure rate and failure of PZQ to eradicate infection in several endemic foci have been reported [29]. Besides, the drug has much less effect against juvenile schistosomes [30]

In view of these observations, there is urgent need now for research and development of novel antischistomal agents as alternatives to PZQ or to use adjuvants to increase its effect. Omeprazole is one of the most commonly prescribed proton pump inhibitors [31]. It has been investigated in treatment of many parasitic disorders as it is effective in reducing inflammation [32], has antioxidant effects [33], and leads to decreased fibrosis [34]. It had been examined in vitro against $\mathrm{S}$. mansoni by Almeida and his colleagues [12], they concluded that it helps to increase the effect of PZQ against S. mansoni parasite.
In the current study, the percentage of worm reduction was significantly increased in S. mansoniinfected mice in combined treated groups at 6 weeks Pi (89.43\%) as compared to mice treated with PZQ or omeprazole alone. However, no statistical significant difference could be detected in omeprazole treated group $(p>0.05)$. This is a sign of the powerful effect of the combination on the juvenile S. mansoni parasites.

The results of the present work goes hand in hand with that of Almeida et al., [12] who showed that omeprazole alone had no effect on S. mansoni worms and it only had effect when given with PZQ. It seems that the synergistic action of omeprazole and PZQ against PZQ-stressed S. mansoni could be dependent on the increased expression of the ATP1A2 Na/K-ATPase caused by PZQ. This would suggest that omeprazole is counteracting the increased $\mathrm{Na} / \mathrm{K}$-ATPase activity in PZQ-stressed S. mansoni parasites.

On the other hand, it is known that omeprazole also targets the ATP-dependent efflux transporter P-glycoprotein [35]. Therefore, there is a possibility that omeprazole would similarly act through inhibition of the P-glycoprotein in PZQ-stressed parasites, to increase the retention of PZQ and parasite susceptibility [36]

ATP1A2 gene product is one of the possible drug targets of omeprazole. In adult worms, ATP1A2 expression was increased upon exposure of the worms to PZQ. Hence, inhibition of ATP1A2 by omeprazole in the presence of PZQ would increase the mortality of adult worms [12]

This is in contrast to the effect of omeprazole on protozoans which are killed by omeprazole alone $[37,38]$. Omeprazole alone can inhibit bloodstage Plasmodium falciparum [11]. Also, omeprazole alone showed in vitro antiprotozoal activity against Trichomonas vaginalis, Giardia intestinalis and Entamoeba histolytica [38].

In addition, omeprazole has already been shown to be synergistic with the first-line treatment drug quinine against Plasmodium falciparum. It may inhibit its growth by inhibiting parasite ATPase activity, which, in turn, increases the $\mathrm{pH}$ of the acidic food vacuole [39]. The Plasmodium genome contains at least two conserved predicted ATP synthases with homology to the mammalian proton ATPase subunit. Thus, it is possible that inhibition of this parasite ATP synthase is responsible for the observed activity of omeprazole. Also, existing studies on omeprazole suggest two potential routes 
of Plasmodium falciparum inhibition: $\mathrm{A} \mathrm{pH}-$ dependent mechanism or liver cell metabolism [37]

Jiang et al., [10] have shown that in Leishmania donovani the antiparasitic action of omeprazole is due to its inhibition of the P-type K/H-ATPase on the surface membrane of the parasite. Since omeprazole is a lysosomotropic drug, it is attractive as a potential chemotherapeutic agent for the treatment of intracellular parasites, such as Leishmania.

These data are also in agreement with the results of Ali Khan and Howden, [40] who reported that monotherapy with omeprazole is ineffective in eradicating Helicobacter pylori infection. However, the addition of omeprazole to a combination of antibiotics improves eradication rates compared to those achieved with antibiotics alone. The explanation is that omeprazole elevates intragastric $\mathrm{pH}$ levels and optimizes the antibacterial action of concomitantly administered antibiotics. Also, omeprazole decreases gastric secretory volume so it increases the concentration of antibiotics within the stomach. Omeprazole was prescribed to Helicobacter pylori-infected subjects in combination with antibiotics during eradication treatment [41]

Results of the present study showed that administration of PZQ resulted in a statistical significant reduction in worms at 6 weeks P.I. (68.79\%) $(p<0.001)$. The main explanation for these results is that PZQ disrupts $\mathrm{Ca} 2+$ homeostasis in worms, which induces a spasmodic contraction of worm musculatures and then the worm's body becomes immobilize with feeble movement of oral sucker, which results in hepatic shift of schistosomes from mesenteric veins to the liver. The tegument of the worm suffers severe destruction revealed in extensive swelling, erosion, vacuolization, and peeling which results in exposure of the worm surface antigen and disruption of the concomitant immune mechanism occurring between the host and schistosomes [42]. Furthermore, Xiao [43] also indicated that the killing process of schistosomes induced by PZQ comprises mainly two aspects which are the direct effect of PZQ on schistosomes and the host immune reaction.

As regards the effect of PZQ on the liver egg loads in the current work, administration of PZQ resulted in a statistical significant reduction $(p<$ 0.001 ) in the eggs per gram of liver when compared with the corresponding controls. Although the reduction of the eggs per gram of liver in the omeprazole only treated group versus the infected control group was insignificant $(p>0.05)$, its co-administration with PZQ showed the highest statistical significant reduction in the eggs per gram of liver tissues at 6 weeks P.I. (96.78\%).

There was a significant reduction in egg count in liver tissue in the group treated with PZQ which came in accordance with that of several workers who tested the effect of PZQ on murine schistosomiasis $[\mathbf{4 4 , 4 5}]$. The main explanation for these results is that PZQ treatment with the killing of the worms; cut the source of eggs in the tissues [46]. This may be attributed to marked decrease in the worm number or fecundity due to hindering the process of oviposition [47]

In the current work, the combined treated group had a great positive impact on bilharzial hepatic pathology as it resulted in a highly significant reduction $(p<0.001)$ in the number $(77.62 \%)$ and diameter $(67.62 \%)$ of the detected granulomas $(p<0.001)$ at 6 weeks P.I. Treatment of infected mice with PZQ showed a statistical significant reduction in the number $(37.41 \%)$ and diameter $(35.86 \%)$ of hepatic granulomas at 6 weeks P.I. Treatment of infected mice with omeprazole showed a statistical significant reduction in the diameter of hepatic granulomas. However, no statistical significant difference in the number of granulomas could be detected in omeprazole treated group.

Concerning the histopathological examination of the liver tissues in the present study, liver sections of infected-untreated mice sacrificed 6 weeks P.I. showed multiple schistosomal granulomas. The majority of them were of cellular type. In the PZQ treated mice, small sized granuloma with moderate inflammatory cellular infiltrate. Liver sections from all mice in combined treated group showed smaller cellular granulomas. Liver sections from all mice in group treated with omeprazole alone showed decrease in the size of granulomas which are mainly cellular with decrease in the inflammatory cells.

These histopathological findings go hand in hand with that of Ghebremariam et al., [48] who showed that heamatoxylin and eosin stains of lungs from bleomycin-injured animals that received prophylactic esomeprazole treatment displayed minimal inflammation with about a third of the animals in this group showing virtually no inflammation suggesting that proton pump inhibitors have potent anti-inflammatory property in vivo and may be therapeutically useful in extra-intestinal inflammatory diseases.

In this work, although all treated groups revealed significant diminution of granuloma diam- 
eter, but the combined treated groups revealed more diminution in granuloma diameter. The current study revealed that treatment of infected mice with PZQ significantly decreased granuloma number and diameter with the majority of granulomas were of cellular types at 6 weeks P.I. In agreement with results of the present study, Elhenawy et al., [45] reported that in the group of PZQ treated mice, most of the liver tissue sections showed minimal to mild infiltrate with a few number of marked infiltrate.

Based on the results of the present study, it could be concluded that the combination of PZQ with omeprazole seems to have a potent synergistic effect in the treatment of schistosomiasis. This was proved by a higher significant reduction in the worm counts, the liver egg loads and the number and diameter of the detected granulomas in liver section as compared to the effect of PZQ alone. Therefore, the combination of PZQ with omeprazole could be considered a promising chemotherapy for the treatment of schistosomiasis and needs further investigations in experimental animals and human.

\section{Conflict of interest:}

None declared.

\section{References}

1- COLLEY D.G., BUSTINDUY A.L., SECOR W.E. and KING C.H.: Human schistosomiasis. Lancet, 383 (9936): 2253-2264, 2014.

2- EL RIDI R., OTHMAN A.A. and McMANUS D.P.: Editorial: The Schistosomiasis Vaccine - It is Time to Stand up. Front. Immunol., 6: 390, 2015.

3- MASAMBA P., ADENOWO A.F., OYINLOYE B.E. and KAPPO A.P.: Universal Stress Proteins as New Targets for Environmental and Therapeutic Interventions of Schistosomiasis. Int. J. Environ. Res. Public Health, 13 (10): 972-984, 2016.

4- BERGQUIST R.: Closing in on "perhaps the most dreadful of the remaining plagues": An independent view of the multidisciplinary alliance to optimize schistosomiasis control in Africa. Acta. Trop., 128 (2): 179-181, 2013.

5- ABATH F.G.C., EDENEIDE M.X., ALLEN R., GOMES Y.M., LUCENA-SILVA N., BALIZA M. and SIMPSON A.J.G.: Characterization of Sm13, a tegumental antigen of Schistosoma mansoni. Parasitol. Res., 86: 745-752, 2000.

6- DOENHOFF M.J., CIOLI D. and UTZINGER J.: Praziquantel: Mechanism of action, resistance and new derivatives for schistosomiasis. Curr. Opin. Infect. Dis., 21: 659-667, 2008

7- FELLENIUS E., BERGLINDH T., SACHS G., OLBE L., ELANDER B., SJOSTRAND S.E. and WALLMARK B.: Substituted benzimidazoles inhibit gastric acid secretion by blocking (H+, K+) ATPase. Nature, 290: 159-161, 1981.
8- IWAHI T., SATOH H., NAKAO M., IWASAKI T., YAMAZAKI T., KUBO K., TAMURA T. and IMADA A.: Lansoprazole, a novel benzimidazole proton pump inhibitor, and its related compounds have selective activity against Helicobacter pylori. Antimicrob. Agents Chemother., 35: 490-496, 1991.

9- BELLI W.A. and FRYKLUND J.: Partial characterization and effect of omeprazole on ATPase activity in Helicobacter pylori by using permeabilized cells. Antimicrob. Agents Chemother., 39: 1717-1720, 1995.

10- JIANG S., MEADOWS J., ANDERSON S.A. and MUKKADA A.J.: Antileishmanial activity of the antiulcer agent omeprazole. Antimicrob. Agent Chemother., 46: 2569-2574, 2002.

11- RIEL M.A., KYLE D.E., BHATTACHARJEE A.K. and MILHOUS W.K.: Efficacy of proton pump inhibitor drugs against Plasmodium falciparum in vitro and their probable pharmacophores. Antimicrob. Agent Chemother., 46: 2627-2632, 2002

12- ALMEIDA G.T., LAGE R.C.G., ANDERSON L., VENANCIO T.M., NAKAYA H.I., MIYASATO P.A., ROFATTO H.K., ZERLOTINI A., NAKANO E., OLIVEIRA G. and VERJOVSKI-ALMEIDA S.: Synergy of Omeprazole and Praziquantel In Vitro Treatment against Schistosoma mansoni Adult Worms. PLoS Negl. Trop. Dis., 9 (9): 4086-4108, 2015.

13- SHAHEEN A.A., ABD EL-FATAH A.A. and EBEID F.A.: Effects of praziquantel treatment on lipid peroxide levels and superoxide dismutase activity in tissues of healthy and Schistosoma mansoni infected mice. Arzneimittelforschung., 44: 94-96.

14- TIAN A., XU T., LIU K., ZOU Q. and YAN X.: AntiHelicobacter pylori effect of total alkaloids of sophora alopecuroides in vivo. Chin. Med. J., 127 (13): 2484 2491,2014

15- HOLANDA J.C., PELLEGRINO J. and GAZZINELLI G.: Infection of mice with cercariae and schistosomula of Schistosoma mansoni by intravenous and subcutaneous routes. Rev. Inst. Med. Trop., 16: 132-134, 1974.

16-DUVALL R.H. and De WITT W.B.: An improved perfusion technique for recovering adult schistosomes from laboratory animals. Am. J. Trop. Med. Hyg., 16: 483-486, 1967.

17- CHEEVER A.W.: Conditions affecting the accuracy of potassium hydroxide digestion in techniques for counting Schistosoma mansoni eggs in tissues. Bull. World Health Organ, 39: 328-331.

18- BANCROFT J.D. and STEVEN A.: Histopathological stains and their diagnostic uses, 1 st ed. Churchill Livingstone, New York, pp. 1-20, 1975.

19- JACOBS W., BOGERS J., DEELDER A., WÉRY M. and VAN MARCK E.: Adult Schistosoma mansoni worms positively modulate soluble egg antigen-induced inflammatory hepatic granuloma formation in vivo. Stereological analysis and immunophenotyping of extracellular matrix proteins, adhesion molecules, and chemokines. Am. J. Pathol., 150 (6): 2033-2045, 1997.

20- ANGAYE T.C.N.: A Review on the Epidemiology and Control of Schistosomiasis in Nigeria. J. Med. Health Res., 1 (2): 1-23, 2016. 
21- LIANG Y.J., YUAN Q., ZHENG D., LIU Y.P., SHI L., ZHOU Y., CHEN A.L., REN Y.Y., SUN K.Y., SUN Y., WANG Y. and ZHANG Z.S.: New insight into the antifibrotic effects of praziquantel on mice in infection with Schistosoma japonicum. PLOS One, 6 (5): e20247, 2011.

22- WHO: Summary of global update on preventive chemotherapy implementation in 2015. Wkly Epidemiol. Rec., 91 (39): 456-459, 2016.

23- AHMAD A. and AHMAD R.: Understanding the mechanism of hepatic fibrosis and potential therapeutic approaches. Saudi J. Gastroenterol., 18: 155-167, 2015.

24- INAGAKI Y., NEMOTO T., KUSHIDA M., SHENG Y. and HIGASHI K.: Interferon alfa down-regulates collagen gene transcription and suppresses experimental hepatic fibrosis in mice. Hepatol., 38: 890-899, 2003.

25- ROBERT B., JÜRG U. and JENNIFER K.: Controlling schistosomiasis with praziquantel: How much longer without a viable alternative? Infect. Dis. Poverty, 6: 74, 2017.

26- GONNERT R. and ANDREWS P.: Praziquantel, a new broad spectrum anti-schistosomal agent. Parasitenkd, 52: 129-150, 1977.

27- CIOLI D.: Praziquantel: Is there real resistance and are there alternatives. Curr. Opin. Infect. Dis., 13: 659-63, 2000.

28- FALLON P.G. and DOENHOFF M.J.: Drug- resistant schistosomiasis: Resistance to praziquantel and oxamniquine induced in Schistosoma mansoni in mice is drug specific. Am. J. Trop. Med. Hyg., 51: 83-88, 1994.

29- HANALLAH S., EL-LAKKANY N., MAHMOUD S., MOUSA M. and BOTROS S.: Altered immunoglobulin isotype profile and anti-immature worm surface immunoglobulin in mice harboring a praziquantel-resistant Schistosoma mansoni isolate. APMIS, 111: 1125-1132, 2003.

30- XIAO S.H., YUE W.J., YANG Y.Q. and YOU J.Q. 1987: Susceptibility of Schistosoma japonicum of different developmental stages to praziquantel. Chin. Med. J., 100: 759-768, 2003.

31- LUNDELL L.: The physiological background behind and course of development of the first proton pump inhibitor. Scand J. Gastroenterol., 50 (6): 680-684, 2015.

32- KEDIKA R.R., SOUZA R.F. and SPECHLER S.J.: Potential Anti-inflammatory Effects of Proton Pump Inhibitors: A Review and Discussion of the Clinical Implications. Dig. Dis. Sci., 54 (11): 2312-2317, 2009.

33- NAMAZI M.R. and JOWKAR F.: A succinct review of the general and immunological pharmacologic effects of proton pump inhibitors. J. Clin. Pharm. Ther., 33: 215217,2008

34- GHEBRE Y.T. and RAGHU G. (2016): Idiopathic pulmonary fibrosis: Novel concepts of proton pump inhibitors as antifibrotic drugs. Am. J. Respir. Crit. Care Med., 193: 1345-1352, 2008.

35- PAULI-MAGNUS C., REKERSBRINK S., KLOTZ U. and FROMM M.F.: Interaction of omeprazole, lansoprazole and pantoprazole with P-glycoprotein. Naunyn Schmiedebergs Arch. Pharmacol., 364: 551-557, 2001.
36- KASINATHAN R.S., SHARMA L.K., CUNNINGHAM C., WEBB T.R. and GREENBERG R.M.: Inhibition or knockdown of $\mathrm{ABC}$ transporters enhances susceptibility of adult and juvenile schistosomes to Praziquantel. PLoS Negl. Trop. Dis., 8: e3265, 2014.

37- DERBYSHIRE E.R., PRUDENCIO M., MOTA M.M. and CLARDY J.: Liver-stage malaria parasites vulnerable to diverse chemical scaffolds. Proc. Natl. Acad. Sci. USA, 109 (22): 8511-8516, 2012.

38- PÉREZ-VILLANUEVA J., ROMO-MANCILLAS A., HERNÁNDEZ-CAMPOS A., YÉPEZ-MULIA L., HERNÁNDEZ-LUIS F. and CASTILLO R.: Antiprotozoal activity of proton-pump inhibitors. Bioorg. Med. Chem. Lett., 21 (24): 7351-7354, 2011.

39- SKINNER-ADAMS T.S. and DAVIS T.M.: Synergistic in vitro antimalarial activity of omeprazole and quinine. Antimicrob. Agent Chemother., 43: 1304-1306, 1999.

40- ALI KHAN M. and HOWDEN C.W.: The Role of Proton Pump Inhibitors in the Management of Upper Gastrointestinal Disorders. Gastroenterol. Hepatol., 14 (3): 169175, 2018.

41- MARÓSTICA M., ARÇARI D.P., BARTCHEWSKY W. JR., TREVISAN M., RIBEIRO M.L., PEDRAZZOLI J. Jr., HOEHR N.F. and GAMBERO A.: Effects of a oneweek treatment with acid gastric inhibitors on Helicobacter pylori-infected mice. Scand J. Gastroenterol., 42 (12): 1404-14 12, 2007.

42- XIAO S.H.: Study progress on the mode of action of praziquantel against schistosomes. Chin. J. Parasitol. Parasit. Dis., 25: 492-502, 2007.

43- XIAO S.H.: Impact of host factors on the schistosomekilling process induced by praziquantel. Chin. J. Parasitol. Parasit. Dis., 26: 217-225, 2008.

44- HUANG Y.X., XU Y.L., YU C.X. LI, H.J., YIN X.R., WANG T.S., WANG W. and LIANG Y.S.: Effect of praziquantel prolonged administration on granuloma formation around Schistosoma japonicum eggs in lung of sensitized mice. Parasitol. Res., 109: 1453-1459, 2011.

45- ELHENAWY A.A., ASHOUR R.H., NABIH N., SHALABY N.M. and MEGAHED N.: Possible antifibrotic effect of GDC-0449 (Vismodegib), a hedgehog-pathway inhibitor, in mice model of Schistosoma-induced liver fibrosis. Parasitol. Int., 66: 545-554, 2017.

46- GARBA A., TOHON Z., SIDIKI A., CHIPPAUX J.P. and De CHABALIER F.: Efficacity of praziquantel in schoolaged children in a hyperendemic zone for Schistoma haematobium (Niger, 1999). Bull. Soc. Pathol. Exot., 94 (1): 42-45, 2001.

47- GUIRGUIS F.R.: Efficacy of praziquantel and Ro 155458, a qacridanonchydrazone derivative, against Schistosoma haematobium. Arzeim Forsch Drug Res., 53 (1): 57-61, 2003.

48- GHEBREMARIAM Y.T., COOKE J.P., GERHART W., GRIEGO C., BROWER J.B., DOYLE-EISELE M., MOELLER B.C., ZHOU Q., HO L., DE ANDRADE J., RAGHU G, PETERSON L., RIVERA A. and ROSEN G.D. Pleiotropic effect of the proton pump inhibitor esomeprazole leading to suppression of lung inflammation and fibrosis. J. Transl. Med., 13: 249-268, 2015. 


\section{عقار الأوميبرازول كعامل مساعد لعقار البرازيكوانتيل

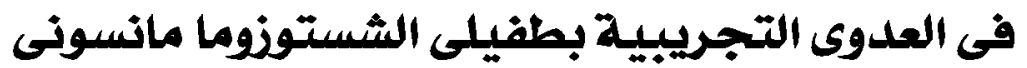

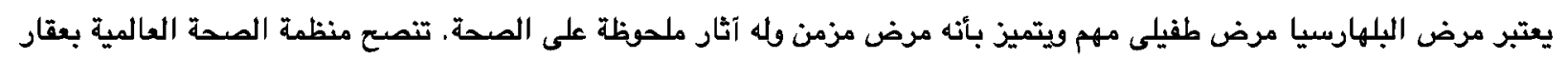

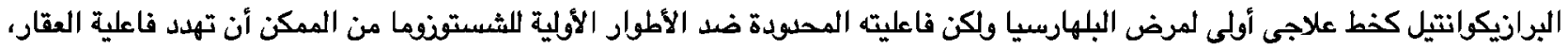

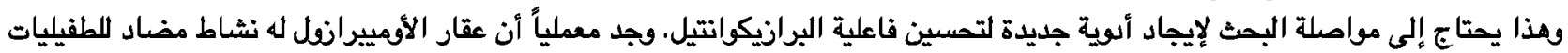

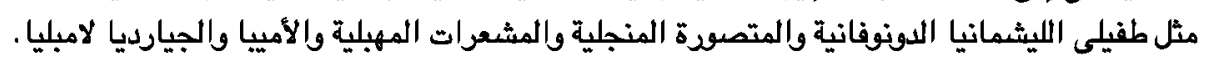

يهدف هذا البحث: إلى تقييم عقار الأومييرانول كعامل معاعد لعقار البرازيكوانتيل فى الفئران المصابة بطفيلى الشستونوما مانسونى.

طريقة البحث: تمت هذه الدراسة على مائة من فئران التجارب البيضاء الصفيرة وقد قسمت إلى ثلاث مجموعات كالأتى: المجموعة الأولى

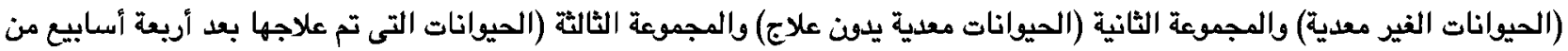

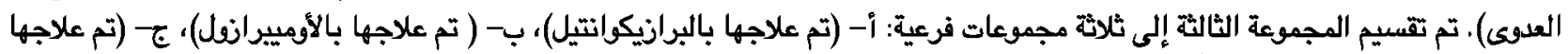

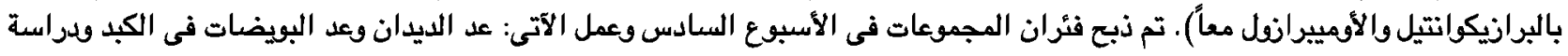

هستوباثولوجية.

أظهرت النتائج إنخفاضاً ملحوظاً فى عدد الديدان وعدد البويضات بالكبد وتحسناً في التغيرات الهستوباثولوهية فى الكبد فى المجموعات

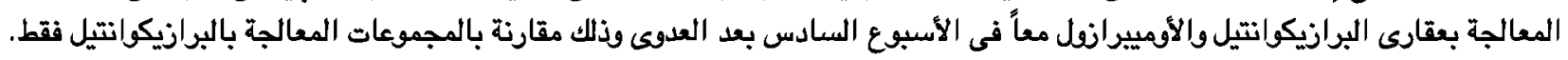

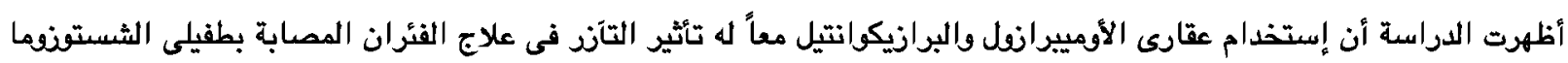

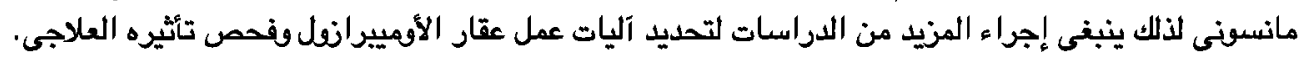

